\title{
Species composition and diversity of morphotypes in epilithic biotopes of Zhytomyr region, Ukraine
}

\author{
MARINA PATSYUK \\ Zhytomyr Ivan Franko State University, Vel. Berdychivska st., 40, Zhytomyr, 10008 Ukraine, ORCID: 0000-0003-1185-8101 \\ Corresponding author e-mail: kostivna@ukr.net
}

Keywords naked amoebae, morphotypes, epilithic biotopes, Zhytomyr region

Abstract $\quad 16$ species of naked amoebae are recorded in the eplithic biotopes of Zhytomyr region, Ukraine: Saccamoeba sp. (1), Saccamoeba sp. (2), Saccamoeba sp. (3), Cashia limacoides Page, 1974, Thecamoeba striata (Penard, 1890) Schaeffer, 1926, Thecamoeba sp., Stenamoeba stenopodia (Page, 1969) Smirnov et al., 2007, Mayorella cantabrigiensis Page, 1983, Mayorella sp., Korotnevella sp., Vexillifera sp., Vannella sp., Ripella platypodia Smirnov, Nassonova, Chao et Cavalier-Smith, 2007, Acanthamoeba sp. (1), Cochliopodium sp., Vahlkampfia sp. (1). The frequency of occurrence in samples is highest for Thecamoeba sp., Mayorella sp., Vahlkampfia sp. (1), Korotnevella sp., Vannella sp., and is lowest for Saccamoeba sp. (1), C. limacoides, M. cantabrigiensis, Cochliopodium sp., S. stenopodia, $R$. platypodia, T. striata, Saccamoeba sp. (2). The species and morphotype diversity of naked amoebae of the epilithic mosses and lichens is influenced by the humidity and the height above soil of the substrate. The species and morphotype diversity of naked amoebae decreases with the increase in height above soil and the decrease of humidity of substrate. We recorded naked amoebae of 9 morphotypes: monotactic, dactylopodial, fan-shaped, lens-like, lingulate, mayorellian, striate, acanthopodial, and eruptive. Amoebae of the lens-like and fan-shaped morphotypes disappear with the increase of height of substrate above soil.

\section{Skład gatunkowy i zróżnicowanie morfotypów w biotopach epilitycznych regionu żytomirskiego na Ukrainie}

Słowa kluczowe ameby nagie, morfotypy, biotopy epiliptyczne, region Zhytomyr

Streszczenie

W eplitycznych biotopach rejonu Żytomierza na Ukrainie odnotowano 16 gatunków nagich ameb: Saccamoeba sp. (1), Saccamoeba sp. (2), Saccamoeba sp. (3), Cashia limacoides Page, 1974, Thecamoeba striata (Penard, 1890) Schaeffer, 1926, Thecamoeba sp., Stenamoeba stenopodia (Page, 1969) Smirnov et al., 2007, Mayorella cantabrigiensis Page, 1983, Mayorella sp., Korotnevella sp., Vexillifera sp., Vannella sp., Ripella platypodia Smirnov, Nassonova, Chao et Cavalier-Smith, 2007, Acanthamoeba sp. (1), Cochliopodium sp., Vahlkampfia sp. (1). Frekwencja w próbach była najwyższa dla Thecamoeba sp., Mayorella sp., Vahlkampfia sp. (1), Korotnevella sp., Vannella sp., a najniższa dla Saccamoeba sp. (1), C. limacoides, M. cantabrigiensis, Cochliopodium sp., S. stenopodia, R. platypodia, T. striata, Saccamoeba sp. (2). 
Na różnorodność gatunkową i morfotypową nagich ameb mchów epilitycznych i porostów ma wpływ wilgotność i wysokość podłoża nad ziemią. Zróżnicowanie gatunkowe i morfotypowe nagich ameb zmniejsza się wraz ze wzrostem wysokości nad ziemią i spadkiem wilgotności podłoża. Odnotowano 9 morfotypów nagich ameb: monotaktyczne, daktylopodialne, wachlarzowate, soczewkowate, jęczmienne, majorelijskie, prążkowane, akantopodialne i wyrzynające się. Ameby soczewkowatych i wachlarzowatych morfotypów zanikają wraz ze wzrostem wysokości podłoża nad glebą.

\section{Introduction}

The naked amoebae are widely distributed in soils, freshwater and saltwater biotopes. For most protists, humidity is the limiting factor in terrestrial biotopes (Bonnet, 1973). The majority of known species of protists are small, which allows them to live in thin films on substrates (Bonnet, 1973; Schonborn, 1989; Korganova, 2003).

There have been no previous reports of the amoebic fauna of epilithic mosses and lichens. For Ukraine, there are only reports of the species compositions of amoebae in the water bodies and the soils (Patcyuk, Dovgal, 2012; Patsyuk, 2014-2020). Hence, any new data on species of these protists from various biotopes of Ukraine is valuable for science.

\section{Materials and methods}

Material was collected during two field trips in the forests of Zhytomyr region (near Zhytomyr city, Denyshi village, Novohrad-Volynsky district, and Olevsk district) in 2019. 162 samples were analyzed. The species composition of naked amoebae was studied in soils and in the mosses and lichens growing on the soils and the rocks near water bodies. Sphagnum spp. dominated in the moss cover, Hypogymnia spp. in that of lichens. The collected samples were stored in zip-lock bags and transferred to the laboratory. $5 \mathrm{~g}$ of substrate sample was placed in a flask of $150 \mathrm{ml}$ with $100 \mathrm{ml}$ of distilled water for 2 hours, after which the mixture was shaken. $10 \mathrm{ml}$ of the mixture was evenly distributed in a Petri dish with non-nutrient agar. The amoebae were cultured after Page's method (Page, 1991).

The amoebae cultures were maintained at $20^{\circ} \mathrm{C}$. Alive protist cells were observed in water droplets on slides, using Axio Imager MI light microscope with differential interference contrast.

The amoebae species were identified using the relevant sources (Page, 1988; Page, 1991; Smirnov, Goodkov, 2004; Smirnov et al., 2008; Smirnov et al., 2011).

Current methods do not allow to assess the abundance of amoebae, thus we've analyzed the frequency of occurrence of amoebae in the samples from the epilithic biotopes of Zhytomyr region (calculated as ratio of the samples containing amoebae to all samples). The substrate humidity was established by weight method.

The diversity of the amoeba species and morphotypes were analyzed using the ChekanovskySørensen index, constructing the dendrogram with bootstrap support of nodes in PAST 1.18 (Hammer, 2001). 


\section{Results and discussion}

In total, 16 species of the naked amoebae were found in the epilithic biotopes of Zhytomyr region (Tables 1, 2). The systematics of those protists is given below following the current systematics of eukaryotes (Adl et al., 2019).

Amoebozoa Luhe, 1913

Class Tubulinea Smirnov et al., 2005

Order Euamoebida Lepsi, 1960

Family Hartmannellidae (Volkonsky, 1931) Page, 1974

Genus Saccamoeba Frenzel, 1892

Saccamoeba sp. (1)

Saccamoeba sp. (2)

Saccamoeba sp. (3)

Genus Cashia Page, 1974

Cashia limacoides Page, 1974

Class Discosea Cavalier-Smith et al., 2004

Order Thecamoebida Schaeffer, 1926

Family Thecamoebidae Schaeffer,1926

Genus Thecamoeba Fromentel, 1874

Thecamoeba striata (Penard, 1890) Schaeffer, 1926

Thecamoeba sp.

Family Stenamoebidae Cavalier-Smith, 2016

Genus Stenamoeba Smirnov et al., 2007

Stenamoeba stenopodia (Page, 1969) Smirnov et al., 2007

Order Dermamoebida Cavalier-Smith, 2004

Family Mayorellidae Schaeffer,1926

Genus Mayorella Schaeffer, 1926

Mayorella cantabrigiensis Page, 1983

Mayorella sp.

Order Dactylopodida Smirnov et al., 2005

Family Paramoebidae Poche,1913

Genus Korotnevella Page, 1981

Korotnevella sp.

Family Vexilliferidae Page, 1987

Genus Vexillifera Schaeffer, 1926

Vexillifera sp.

Order Vannellida Smirnov et al., 2005

Family Vannellidae Bovee, 1979

Genus Vannella Bovee, 1965

Vannella sp.

Genus Ripella Smirnov, Nassonova, Chao et Cavalier-Smith, 2007

Ripella platypodia Smirnov, Nassonova, Chao et Cavalier-Smith, 2007

Order Centramoebida (Rogerson and Patterson, 2002) Cavalier-Smith, 2004

Family Acanthamoebidae Sawyer and Griffin, 1975

Genus Acanthamoeba Volkonsky, 1931

Acanthamoeba sp. (1) 
Order Himatismenida Page, 1987

Family Cochliopodiidae De Saedeleer, 1934

Genus Cochliopodium Hertwig et Lesser, 1874

Cochliopodium sp.

Excavata Cavalier-Smith, 2002

Discoba Simpson in Hampl et al., 2009

Class Heterolobosea Page \& Blanton, 1985

Family Vahlkampfiidae Jollos, 1917

Genus Vahlkampfia Chatton et Lalung-Bonnaire, 1912

Vahlkampfia sp. (1)

Hartmannellidae were represented by the maximum number of species (four). There were three species of Thecamoebidae, two of Mayorellidae and of Vannellidae, and one of Paramoebidae, Vexilliferidae, Acanthamoebidae, Cochliopodiidae, Vahlkampfiidae each.

By the frequency of occurrence in the epilithic biotopes of Zhytomyr region, the most common species were Thecamoeba sp. (89\%), Mayorella sp. (83\%), Vahlkampfia sp. (1) (67\%), Korotnevella sp. (61\%), Vannella sp. (50\%); the least common were Saccamoeba sp. (1) (5.0\%), C. limacoides (5.7\%), M. cantabrigiensis (11\%), Cochliopodium sp. (11.3\%), S. stenopodia (13\%), R. platypodia (22\%), T. striata (28\%), Saccamoeba sp. (2) (28\%); Acanthamoeba sp. (1) (39\%) and Vexillifera sp. (45\%) were found with the average frequency of occurrence (Figure 1).

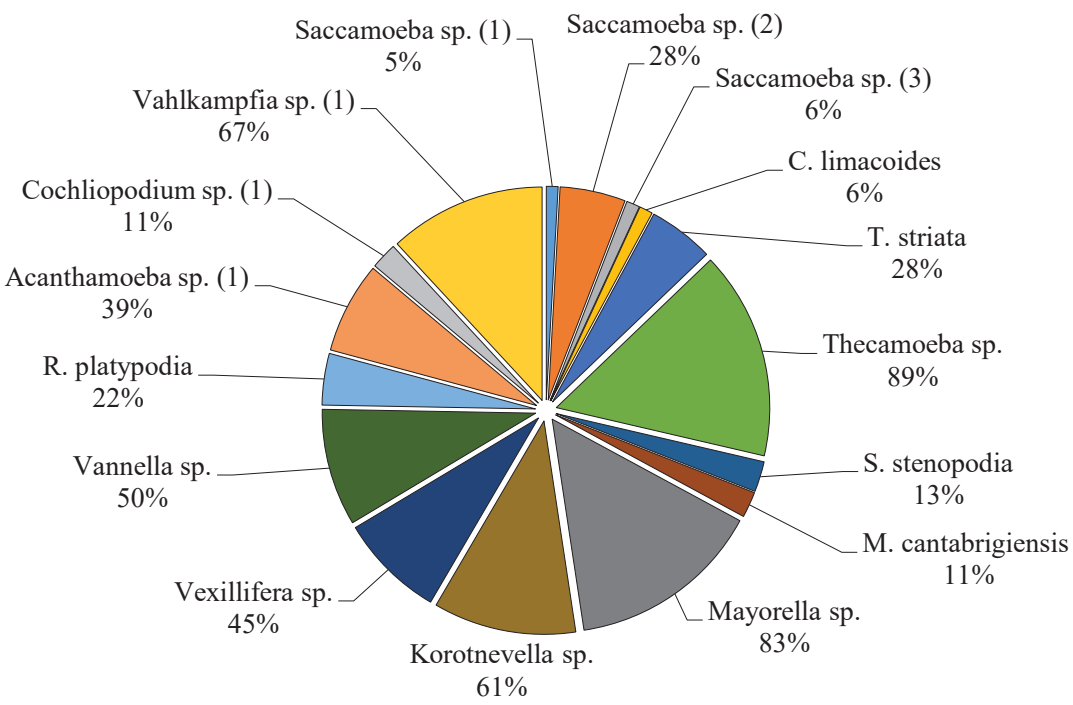

Figure 1. Frequency of occurrence of naked amoebae findings in epilithic mosses and lichens of Zhytomyr region (Ukraine)

We also analyzed the distance of epilithic biotopes to soil (height) as a factor influencing the species diversity of the naked amoebae. With increasing height, the species richness parameters decreased for those protists. The highest number of species was recorded in substrates at the soil 
level (Table 2), including Saccamoeba sp. (1), Saccamoeba sp. (2), Saccamoeba sp. (3), C. limacoides, Korotnevella sp., Vexillifera sp., Vannella sp., Cochliopodium sp., M. cantabrigiensis, Mayorella sp., T. striata, Thecamoeba sp., S. stenopodia, Acanthamoeba sp. (1), Vahlkampfia sp. (1), $94 \%$ of all species identified in the study. By the frequency of occurrence in mosses, the most widely distributed amoebae were Acanthamoeba sp. (1) (95\%), Mayorella sp. (94\%), Vexillifera sp. (93\%), Vahlkampfia sp. (1) (92\%), Thecamoeba sp. (91\%), Korotnevella sp. (84\%), T. striata (70\%), Vannella sp. (67\%), 50\% of all species under study. The most common amoeba species of the epilithic lichens included Thecamoeba sp. (84\%), Mayorella sp. (80\%), Saccamoeba sp. (2) (74\%), Korotnevella sp. (70\%), Vahlkampfia sp. (1) (67\%), Vexillifera sp. (65\%), Vannella sp. $(60 \%), 44 \%$ of the total species diversity. The least common species in the epilithic mosses at soil level were $R$. platypodia (36\%), S. stenopodia (36\%), M. cantabrigiensis (35\%), C. limacoides (33\%), Cochliopodium sp. (32\%); in the epilithic lichens, such species were R. platypodia (37\%), Saccamoeba sp. (3) (36\%), Saccamoeba sp. (1) (33\%), T. striata (28\%), a quarter of all found species of amoebae (Table 1).

Table 1. Frequency of occurrence of naked amoebae in epilithic mosses and lichens of Zhytomyr region (\%)

\begin{tabular}{|r|l|r|r|r|r|r|r|}
\hline \multirow{2}{*}{ No. } & \multirow{2}{*}{ Species of amoebae } & \multicolumn{3}{|c|}{ Mosses } & \multicolumn{3}{c|}{ Lichens } \\
\cline { 3 - 8 } & & $0 \mathrm{~m}$ & $0-0.5 \mathrm{~m}$ & $0.5-1.0 \mathrm{~m}$ & $0 \mathrm{~m}$ & $0-0.5 \mathrm{~m}$ & $0.5-1.0 \mathrm{~m}$ \\
\hline 1. & Saccamoeba sp. (1) & 0 & 0 & 0 & 33 & 0 & 0 \\
\hline 2. & Saccamoeba sp. (2) & 0 & 0 & 0 & 74 & 60 & 30 \\
\hline 3. & Saccamoeba sp. (3) & 0 & 0 & 0 & 36 & 0 & 0 \\
\hline 4. & C. limacoides & 33 & 0 & 0 & 0 & 0 & 0 \\
\hline 5. & T. striata & 70 & 30 & 0 & 28 & 38 & 0 \\
\hline 6. & Thecamoeba sp. & 91 & 76 & 67 & 84 & 93 & 95 \\
\hline 7. & S. stenopodia & 36 & 30 & 0 & 0 & 0 & 0 \\
\hline 8. & M. cantabrigiensis & 36 & 30 & 0 & 0 & 0 & 0 \\
\hline 9. & Mayorella sp. & 94 & 92 & 75 & 80 & 95 & 25 \\
\hline 10. & Korotnevella sp. & 84 & 89 & 41 & 70 & 30 & 33 \\
\hline 11. & Vexillifera sp. & 93 & 74 & 0 & 65 & 35 & 0 \\
\hline 12. & Vannella sp. & 67 & 33 & 0 & 60 & 62 & 58 \\
\hline 13. & R. platypodia & 95 & 36 & 0 & 37 & 28 & 0 \\
\hline 14. & Acanthamoeba sp. (1) & 33 & 0 & 0 & 0 & 33 & 0 \\
\hline 15. & Cochliopodium sp. & 92 & 89 & 50 & 67 & 67 & 32 \\
\hline 16. & Vahlkampfia sp. (1) & & & & & & \\
\hline
\end{tabular}

The diversity of amoebae did not change significantly with the distance between soil and the epilithic mosses and lichens increasing to $0.5 \mathrm{~m}$ (Tables 1,2). At that height, we recorded Vahlkampfia sp. (1), T. striata, Thecamoeba sp., R. platypodia, Vannella sp., S. stenopodia, Mayorella sp., Korotnevella sp., Saccamoeba sp. (2), Cochliopodium sp., Vexillifera sp., Acanthamoeba sp. (1). At the height of $1 \mathrm{~m}$ (above soil), species composition changed and the most common core species were not present. At that height, Mayorella sp. (75\%), Thecamoeba sp. (67\%), Vahlkampfia sp. (1) (50\%), Korotnevella sp. (41\%) were found in the epilithic mosses, and Thecamoeba sp. (95\%), Vannella sp. (58\%), Korotnevella sp. (33\%), Vahlkampfia sp. (1) (32\%), Saccamoeba sp. (2) (30\%), Acanthamoeba sp. (1) (29\%), Mayorella sp. (25\%) in the epilithic lichens (Table 1). 


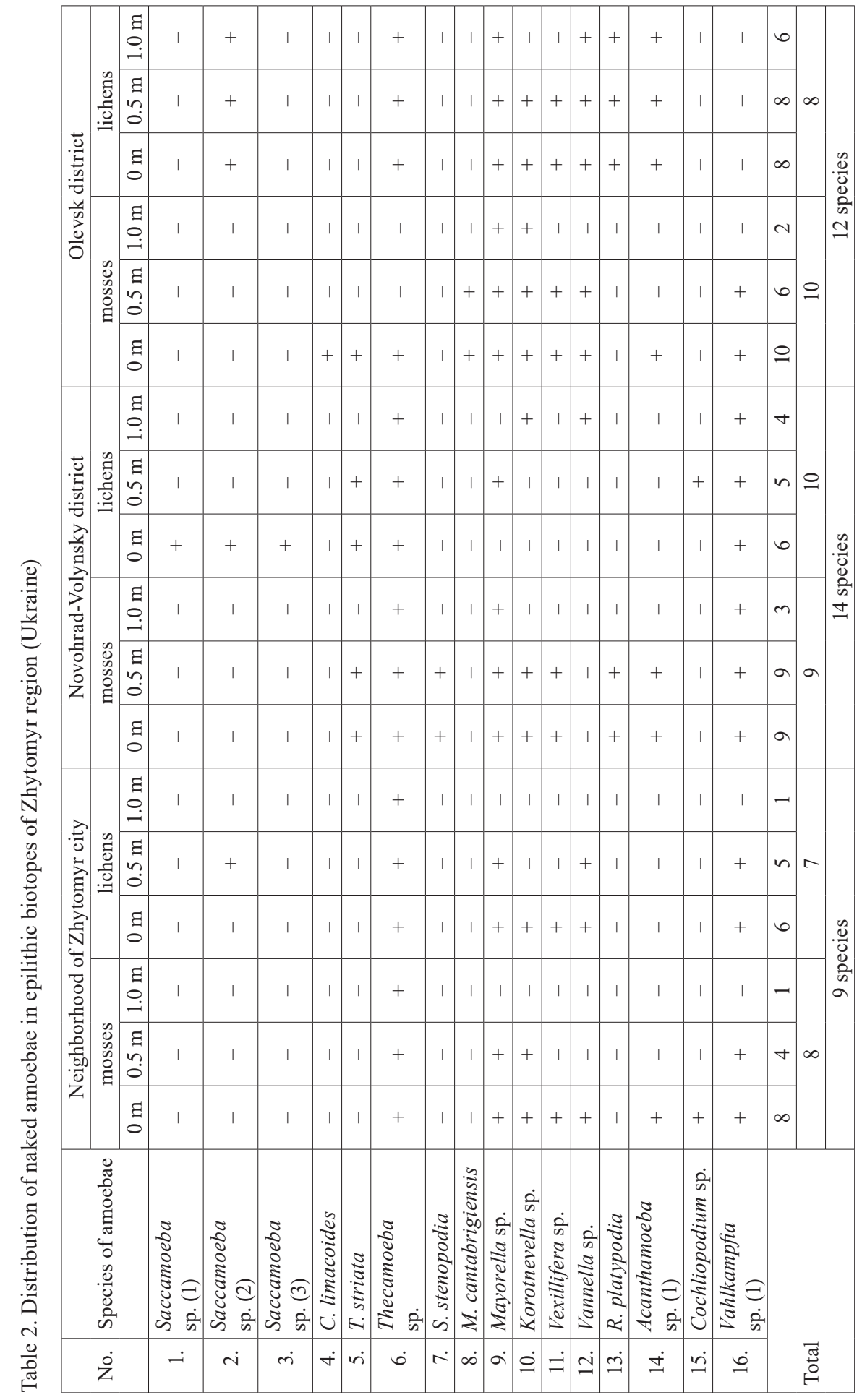


Nine of 16 species of amoebae were found at all heights: Vahlkampfia sp. (1), T. striata, Thecamoeba sp., Vannella sp., Mayorella sp., Korotnevella sp., Saccamoeba sp. (2), Vexillifera sp., Acanthamoeba sp. (1).

C. limacoides, Saccamoeba sp. (1), Saccamoeba sp. (3) were not numerous and preferred the epilithic mosses and lichens at the soil level. At the height of $0.5 \mathrm{~m}$ these species were not found.

The species diversity of amoebae from the epilithic biotopes of Zhytomyr region was compared to that in soil at the ground level and that of epigeic mosses in order to determine the biotope-specific features. The soil-living species included Vahlkampfia sp. (1), C. limacoides, T. striata, S. stenopodia, M. cantabrigiensis, Vannella sp., Acanthamoeba sp. (1), for all of them the frequency of occurrence did not exceed $38 \%$. In the epigeic mosses, Vahlkampfia sp. (1) (15\%), Saccamoeba sp. (1) (3.6\%), Acanthamoeba sp. (1) (12\%) were found. That points to the similarity of the species diversity of amoebae of the epilithic mosses and lichens and that of soils. Besides that, most of the species of our study have been found before in the water bodies of Ukraine (Patcyuk, Dovgal, 2012; Patsyuk, 2014-2020).

The similarity of species composition of the naked amoebae from various epilithic biotopes was analyzed using the Chekanovsky-Sørensen index. At the dendrogram, two clusters can seen (Figure 2). One of the clusters represented the species diversity of amoebae of the epilithic lichens at different height, and that of the epilithic mosses at $0.5 \mathrm{~m}$ above soil. The bootstrap support of that cluster is $47 \%$. The other cluster (bootstrap support $100 \%$ ) represented the amoeba species sampled at $1.0 \mathrm{~m}$ above soil. Its specifics were determined by Vahlkampfia sp. (1), Thecamoeba sp., Mayorella sp., and Korotnevella sp. The index of faunistic similarity was higher than 50\% $(0.50-0.96)$ for the species diversity of amoebae collected in the various epilithic biotopes of Zhytomyr region.

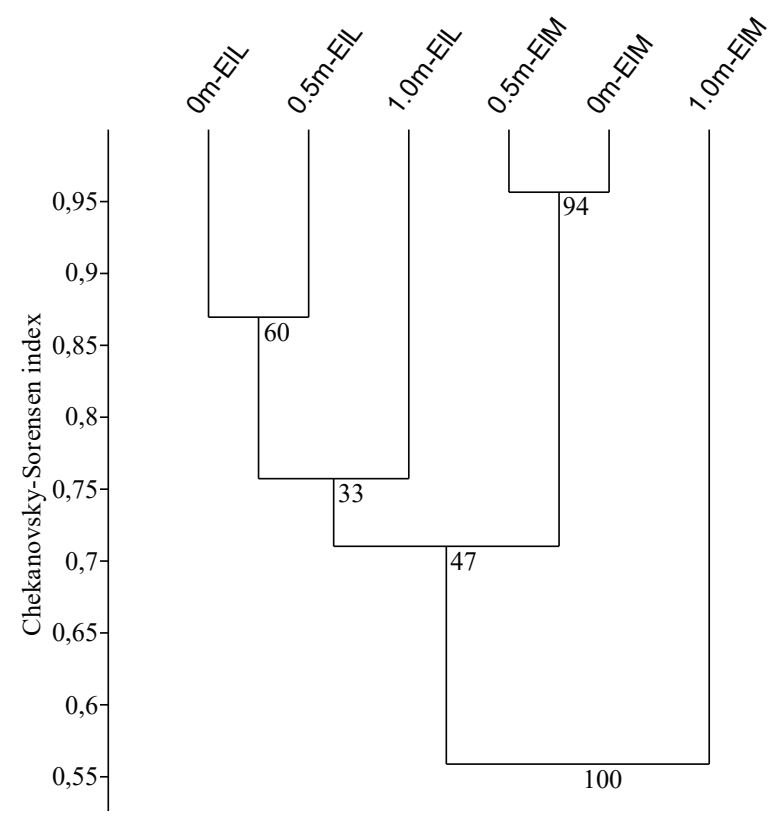

Figure 2. Similarity of species diversity of naked amoebae in epilithic mosses and lichens at different height above soil in Zhytomyr region (ElL - epilithic lichens, ElM - epilithic mosses) 
The species richness of amoebae was defined by the levels of microbiotope humidity. It was relatively high in the moist mosses and lichens (68-78\%). Low values of species richness were found in the driest conditions of the epilithic mosses and lichens (41-44\%). The humidity levels of the epilithic biotopes decreased with the increasing height above soil.

Similar findings have been observed in the studies of relationship between the species composition of other invertebrates (testate amoebae, heterotrophic flagellates, mites, etc.) and the distance from soil (Miller et al., 2007; Lindo et al., 2008).

We have identified amoebae of nine morphotypes in the present study: monotactic (Saccamoeba sp. (1), Saccamoeba sp. (2), Saccamoeba sp. (3), C. limacoides); dactylopodial (Korotnevella sp., Vexillifera sp.); fan-shaped (Vannella sp., R. platypodia); lens-like (Cochliopodium sp.); lingulate (S. stenopodia), mayorellian (M. cantabrigiensis, Mayorella sp.), striate (T. striata, Thecamoeba sp.), acanthopodial (Acanthamoeba sp. (1)), eruptive (Vahlkampfia sp. (1)). Amoebae of the eruptive morphotype were the most common in the epilithic biotopes of Zhytomyr region (67\%), in contrast to those of lingulate (5.5\%) and monotactic (7.4\%) morphotypes. Frequency of occurrence was $20.3 \%$ for fan-shaped amoebae, $22.2 \%$ for lens-like amoebae, $33.3 \%$ for mayorellian and acanthopodial amoebae, $35.2 \%$ for dactylopodial amoebae, and $40 \%$ for the striate amoebae.

All nine morphotypes of amoebae were found in the epilithic mosses of the study region. In the epilithic lichens, the lingulate amoebae were absent. At 0 to $1.5 \mathrm{~m}$ above soil, we found the monotactic, dactylopodial, fan-shaped, mayorellian, striate, acanthopodianl, eruptive morphotypes, making up 78\% of all the recorded morphotypes. Amoebae of the lens-like and the lingulate morphotypes, $22 \%$ of all recorded morphotypes, were not collected at $1.5 \mathrm{~m}$ above soil.

Similarly, all nine morphotypes of amoebae were present in the epilithic mosses at soil level $(0 \mathrm{~m})$. Seven morphotypes of amoebae were observed in the epilithic lichens at that level, with the exception of the lens-like and lingulate morphotypes. In the epilithic mosses at soil level, the most common amoeba were of acanthopodial (98\%), eruptive (95\%), striate $(67 \%)$, mayorellian (67\%), dactylopodial (67\%) morphotypes; the least common were amoebae of monotactic $(5.5 \%)$ and lingulate (17\%) morphotypes; for fan-shaped and lens-like amoebae, the frequency of occurrence was $33 \%$. In the epilithic lichens at soil level, the most common were the amoebae of striate (67\%) and eruptive (70\%) morphotypes. Frequency of occurrence of amoebae of other morphotypes did not exceed $37 \%$ (Figure 3).

At $0.5 \mathrm{~m}$ above soil, the frequency of occurrence and the diversity of amoebae of certain morphotypes did not change essentially (Figure 3). In the epilithic mosses, seven of the morphotypes were represented (78\% of all morphotypes). In the epilithic lichens, the amoebae of eight morphotypes (89\%) were present.

At $1.0 \mathrm{~m}$ above soil the humidity levels and frequency of occurrence of certain amoebic morphotypes were lower. The amoebae of the epilithic mosses at that height were of dactylopodial (11\%), mayorellian (33\%), striate (33\%) and eruptive (41\%) morphotypes. The amoebae of epilithic lichens were of monotactic (5.5\%), dactylopodial (11\%), mayorellian (17\%), fan-shaped (22\%), acanthopodial (31\%), eruptive (33\%) and striate (50\%) morphotypes (Figure 3).

The diversity of amoeba morphotypes was analyzed using Chekanovsky-Sørensen index. The resulting two groups are shown on Figure 4. The first group included the morphotypes of amoebae found in epilithic mosses and lichens $(0-0.5 \mathrm{~m})$, with $76 \%$ bootstrap support. The second group included the morphotypes of amoebae from the epilithic mosses at $1 \mathrm{~m}$ above soil. That complex was defined by the amoebae of dactylopodial, mayorellian, striate and eruptive morphotypes. The results of clustering analysis of the amoeba species diversity were in line with 
these findings. Vahlkampfia sp. (1), Thecamoeba sp., Mayorella sp., Korotnevella sp. formed a separate complex of species, and their morphotypes were grouped similarly.

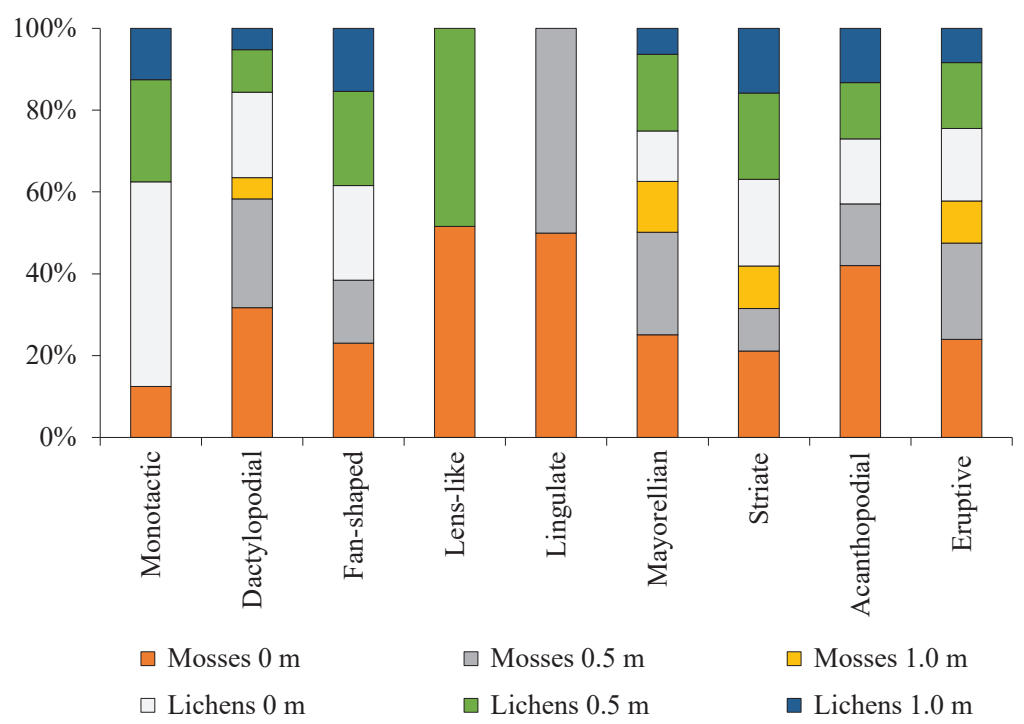

Figure 3. Frequency of occurrence of amoeba morphotypes in epilithic biotopes at different height above soil in Zhytomyr region (Ukraine)

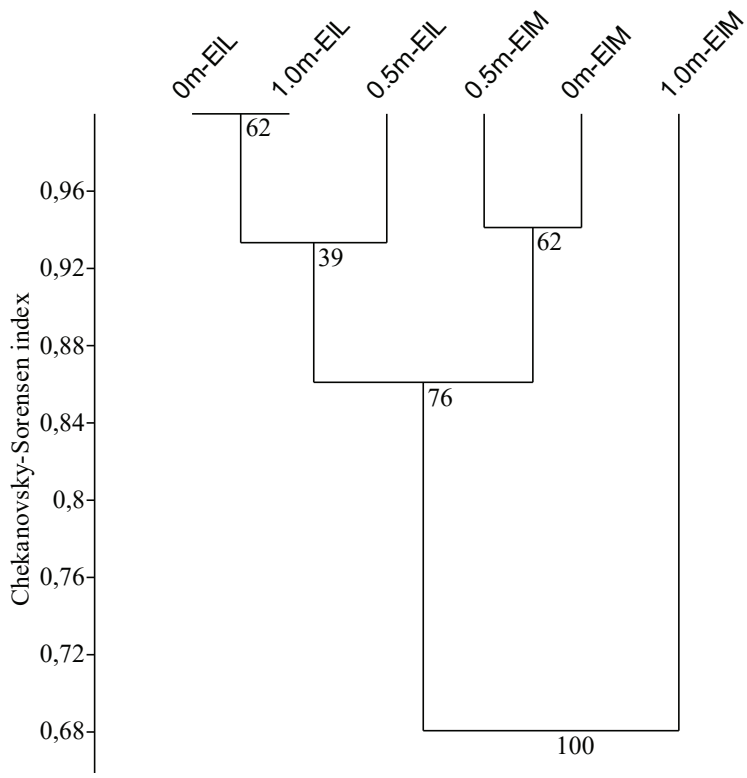

Figure 4. Similarity of morphotype diversity of naked amoeba in epilithic mosses and lichens at different height above soil in Zhytomyr region (EIL - epilithic lichens, ElM - epilithic mosses) 


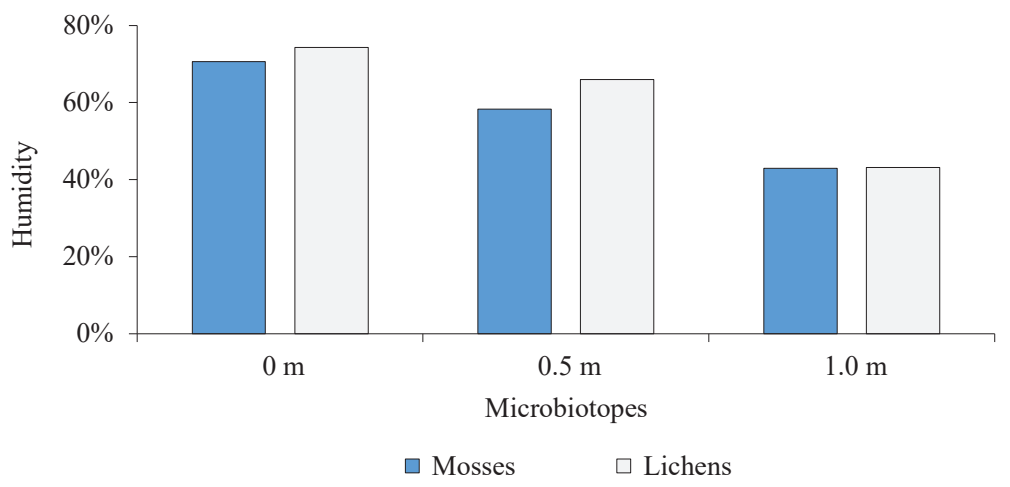

Figure 5. The mean values (in \%) of the change of humidity in the studied microbiotopes with the increasing height above ground

Thus, 16 species of naked amoebae of the molecular clusters of Tubulinea, Discosea and Discoba were identified in present study of the species composition of naked amoebae in the epilithic mosses and lichens of Zhytomyr region, Ukraine. Most species grouped together in clusters are eurybionts found in the water bodies, soils, and epilithic biotopes. The changes in species composition of amoebae in the epilithic mosses and lichens occur at $0.5-1 \mathrm{~m}$ above soil. Factors that determine the species composition of amoebae in such biotopes are distance to soil and humidity levels (Figure 5). According to the cluster analysis, the species diversity of amoebae of the epilithic biotopes of Zhytomyr region consists of two complexes. One of them includes the amoebae of the epilithic lichens at varying height above soil and epilithic mosses at $0.5 \mathrm{~m}$ above soil ( $47 \%$ bootstrap support), the other is formed by of amoebae of the epilithic mosses at $1.0 \mathrm{~m}$ above soil (100\% bootstrap support). In the epilithic mosses of the study region we found amoebae of monotactic, dactylopodial, fan-shaped, lens-like, lingulate, mayorellian, striate, acanthopodial and eruptive morphotypes. The amoebae of lingulate morphotype are not found in the epilithic lichens. At $1.5 \mathrm{~m}$ above soil, the amoebae of the lingulate and lens-like morphotypes are not present. The cluster analysis of the morphotype diversity results in two groups of the amoeba morphotypes similar to the clusters of amoeba species diversity. The species and morphotype compositions of the naked amoebae are similar in structure according to the results of cluster analysis, that is, the representatives of different morphotypes prefer similar ecological conditions.

\section{References}

Adl, S.M., Bass, D., Lane, C.E. et al. (2019). Revisions to the Classification, Nomenclature, and Diversity of Eukaryotes. Journal of Eukaryotic Microbiology, 66, 4-119.

Bonnet, L. (1973). Le peuplement thecamoebien des mousses corticoles. Protistologica, 9, 319-338.

Hammer, O., Harper, D.A.T., Ryan, P.D. (2001). PAST: Palaeontological statistics software package for education and data analysis. Palaeontol. electronica, 4 (1), 1-9.

Korganova, G.A. (2003). Adaptive morphological structures in evolution of soil testate amoebae (Protista, Testacea). Zoologicheskii Zhurn., 82 (2), 197-214 [in Russian]. 
Lindo, Z., Winchester, N., Didham, R. (2008). Nested patterns of community assembly in the colonisation of artificial canopy habitats by oribatid mites. Oikos, 117, 1856-1864.

Miller, K., Wagner, R., Woods, S. (2007). Effect of gap harvesting on epiphytes and bark-dwelling arthropods in the Acadian forest of central Maine. Can. J. For. Res., 37, 2175-2187.

Page, F.C. (1988). A New Key to Freshwater and Soil Gymnamoebea. Freshwater Biological Association, Ambleside, Cumbria, UK, $122 \mathrm{p}$.

Page, F.C., Siemensma, F.J. (1991). Nackte Rhizopoda und Heliozoea (Protozoenfauna Band 2). Stuttgart, New York: Gustav Fischer Verlag.

Patcyuk, M.K., Dovgal, I.V. (2012). Biotopic distribution of naked amoebes (Protista) in Ukrainian Polissya area. Vestnik Zoologii, 46 (4), 355-360.

Patsyuk, M.K. (2014). Morphotypes in Naked Amoebas (Protista): Distribution in Water Bodies of Zhytomyr and Volyn Polissia (Ukraine) and Possible Ecological Significance. Vestnik Zoologii, 48 (6), $547-552$.

Patsyuk, M.K. (2015). Species of naked amoebae (Protista) new for the fauna of Ukraine. Vestnik Zoologii, 5 (49), 387-392.

Patsyuk, M.K. (2016). New Finds of Naked Amoebae (Protista) in Water Reservoirs of Ukraine. Vestnik Zoologii, 50 (4), 291-300.

Patsyuk, M. (2017). Parasitic amoebae found in water bodies of Ukraine. Experimental Parasitology, 183, $81-84$.

Patsyuk, M.K. (2018). Peculiarities of the Spatial Distribution of Naked Amoebas in Sandy Bottom Sediments of a Small River. Hydrobiological Journal, 54 (5), 102-111.

Patsyuk, M.K., Onyshchuk, I.P. (2019). Diversity and Distribution of Naked Amoebae in Water Bodies of Sumy Region (Ukraine). Vestnik Zoologii, 53 (3), 177-186.

Patsyuk, M. (2019). Changed species composition of naked amoebae in soils of forest-and-steppe zone of Ukraine. Acta Biologica, 26, 57-64.

Patsyuk, M. (2020). Diversity of Naked Amoebae in Soils of Forest Areas of Zhytomyr Region (Ukraine). Zootaxa, 4743 (2), 257-265.

Schönborn, W. (1989). The topophenetic analysis as a method to elucidate the phylogeny of testate amebas (Protozoa, Testacealobosia and Testaceafilosia). Arch. Protistenk, 37, 223-245.

Smirnov, A., Goodkov, A. (1999). An illustrated list of basic morphotypes of Gymnamoebae (Rhizopoda, Lobosea). Protistology, 1, 20-29.

Smirnov, A. (2008). Amoebas, Lobose. In: M. Schaechter (ed.), Encyclopedia of Microbiology (pp. 558577). Oxford: Elsevier.

Smirnov, A., Chao, E., Nassonova, E., Cavalier-Smith, T. (2011). A Revised Classification of Naked Lobose Amoebae (Amoebozoa: Lobosa). Protist, 162, 545-570.

Cite as: Patsyuk, M. (2020). Species composition and diversity of morphotypes in epilithic biotopes of Zhytomyr region, Ukraine. Acta Biologica, 27, 31-41. DOI: 10.18276/ab.2020.27-04. 